\title{
Kindler syndrome: A very rare bullosa poikyloderma discovered in a baby
}

\author{
Khadija Elboukhari*, Sara Elloudi, Hanane BayBay and Fatima Zahra Mernissi \\ Departement of Dermatology, University Hospital of Fez, Morocco
}

\begin{abstract}
Kindler syndrome is a very rare bullous dermatosis of the childhood. It is classified as a subtype of epidermolyse bullosa and is characterized by the occurrence of acral predisposing blisters, associated to poikyloderma, skin atrophy and photosensitivity. It may be sporadic or transmitted in an autosomic recessive model. The treatment is preventive and symptomatic. The aim of this article is to describe this syndrome, and explain its pathogeny via a case presentation with a literature review.
\end{abstract}

\section{Introduction}

Kindler syndrome is a very rare bullous dermatosis of the childhood characterized by the occurrence of acral predisposing blister, associated to poikyloderma and varying degree of photosensitivity. It may be sporadic, but it is often transmitted in an autosomic recessive model. The treatment is preventive and symptomatic. We report the case of a baby who presented this disease with a literature review.

\section{Case presentation}

We report the observation of a 9-month-old infant, born of a nonconsanguineous marriage, without similar cases in the family, having presented since the age of 03 months a dyschromic aspect of the face and the genital area. A few months later, he showed tense blisters with clear contents on the acrales zones, evolving in a context of conservation of the general state and a photophobia. On the dermatological examination, we found tense blisters with clear content sitting on the extremities, resting on a slightly atrophic skin (Figure 1), the face and perineum were poikylodermic (Figure 2). It was noted also an eyebrow depilation without abnormalities in the scalp including trichoscopy. There were no abnormalities of dentition or gingival hypertrophy. The patient has benefited from a skin biopsy that found an intraepidermal bullous dermatosis. This clinical presentation being in favor of a Kindler syndrome. The absence of skeletal abnormalities eliminated the Rothmond Thomson syndrome and the presence of excessive bubbles eliminated a Xeroderma Pigmentosum. The patient benefited then from local care. The subsequent control has noted a spontaneous

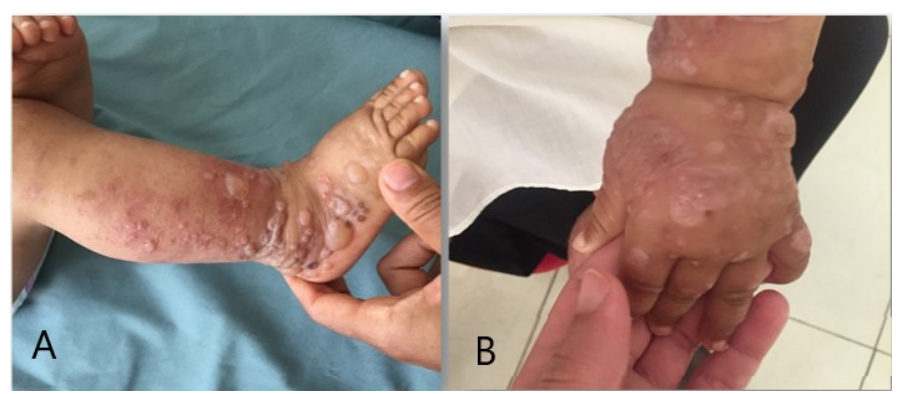

Figure 1. Acral predisposingn blisters with localized skin atrophy (A and B)

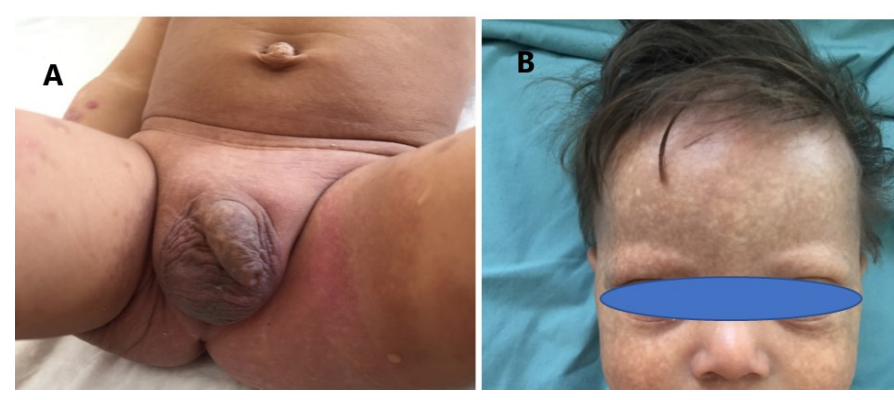

Figure 2. Perineal (A) and facial poikyloderma with eyebrow depilation (B)

regression of blisters with persistence of the poikylodermic aspect that was in favour of our diagnosis. We did not find any other abnormalities to the rest of the somatic examination.

\section{Discussion}

First described in 1954 by Theresa Kindler [1] Kindler syndrome is an hereditary bullous photodermatosis that is characterized by poikiloderma, skin atrophy, trauma-induced blisters and photosentivity [2]. Its a a form of poikyloderma and a subtype of Epidermolys bullosa [3]. The etiopathogeny of this disease is related to an abnoramality in actin cytoskeletton with defficiency of its adherence to the extracellular matrix. Mutation of the FMRT1 gene is behind this disease, it's responsible for the loss of function of a protein FFH2 [4], also known as protein Kindlin -1 which is a protein bound to the cytoskeleton, which will cause a disruption of the keratinocyte adhesion at the dermoepidermal junction [3,5]. The clinical presentation is characterized by the combination of an acute bullous eruption [1], which improves with age as well as was the evolution in our patient

${ }^{*}$ Correspondence to: Khadija Elboukhari, Departement of Dermatology, University Hospital of Fez, Morocco, E-mail: elboukharikhadija89@gmail.com

Key words: Kindler syndrome, poikyloderma, epidermolyse bullosa, photosensitivity

Received: January 15, 2020; Accepted: March 02, 2020; Published: March 05, 2020 
which differentiate this entity from the other forms of Epidermolyse bullosa. In the other hand, we assist to a progressive poikyloderma. Skin atrophy occurs early, especially on the back of the hands and feet. The photosensitivity in this disease is variable. Other clinical signs may mark this syndrome as abnormal oral desquamative gingivitis or destructive periodontal disease [6,7]. Other mucous can be reached in this syndrome, including the urogenital and anal mucosa, digestive involvement as oesophageal stenosis has been described in several patients. Histological features of this disease are not specifics, we found epidermal atrophy, vacuolization of basal keratinocyte, pigmentar inceontinentia and dermal inflammation [7-9]. There is currently no cure for this disease [10], Symptomatic measures include: aseptic rupture of the blisters, the application of emollients improves the skin dryness, the photoprotection reduces the risk of occurrence of cutaneous squamous cell carcinoma and the care of the oral mucosa with a close monitoring will detect a squamous cell carcinoma of the oral mucosa which is a possible complication in this syndrome $[3,11]$.

\section{Conclusion}

Kindler syndrome is a rare genodermatosis, must be evoked in front of a progressive poikyloderma associated with improving acral blisters and a photosensitivity. The oral examination is capital declining a periodontal disease that has to be well treated to avoid degeneration.

\section{References}

1. Kindler T (1954) Congenital poikiloderma with traumatic bulla formation and progressive cutaneous atrophy. Br J Dermatol 66: 104-111.

2. Almeida Jr, HL de, Heckler GT, Fong K, Lai-Cheong J, et al. (2013) Sporadic Kindler Syndrome with a novel mutation. Anais Brasileiros de Dermatologia 88: 212-215.

3. Lai-Cheong JE, McGrath JA (2010) Kindler syndrome. Dermatol Clin 28: 119-124.

4. Jobard F, Bouadjar B, Caux F, Hadj-Rabia S, Has C, et al. (2003) Identification of mutations in a new gene encoding a FERM family protein with a pleckstrin homology domain in Kindler syndrome. Hum Mol Genet 12: $925 \mathrm{e} 35$.

5. Lai-Cheong JE, Tanaka A, Hawche G, Emanuel P, Maari C, et al. (2009) Kindler syndrome: a focal adhesion genodermatosis. British Journal of Dermatology 160: 233-242.

6. Ashton GH (2004) Kindler syndrome. Clin Exp Dermatol 29: 116e21.

7. Wiebe CB, Petricca G, Hakkinen L, Jiang G, Wu C, et al. (2008) Kindler Syndrome and Periodontal Disease: Review of the Literature and a 12-Year Follow-Up Case. $J$ Periodontol 79: 961-966.

8. Krunic ALJ, Ljiljana M, Novak A, Carlos G, Clark RE (1997) Hereditary bullous acrokeratotic poikiloderma of Weary-Kindler associated with pseudoainhum and sclerotic bands. International Journal of Dermatology 36: 529-533

9. Forman AB, Prendiville JS, Esteriy NB, Hebert AA, Duvic M, et al. (1989) Kindler Syndrome: Report of Two Cases and Review of the Literature. Pediatric Dermatology 6: 91-101.

10. Michael M, Begum R, Chan GK, Whitewood AJ, Matthews DR, et al. (2019) Kindlin-1 Regulates Epidermal Growth Factor Receptor Signaling. Journal of Investigative Dermatology 139: 369-379.

11. Souldi H, Bajja MY, Mahtar M (2018) Kindler syndrome complicated by invasive squamous cell carcinoma of the palate. Eur Ann Otorhinolaryngol Head Neck Dis 135: 59-61.

Copyright: (C2020 Elboukhari K. This is an open-access article distributed under the terms of the Creative Commons Attribution License, which permits unrestricted use, distribution, and reproduction in any medium, provided the original author and source are credited. 